\title{
Formal and Non-formal Skills Improvement for the Marginalised Youth in Uganda
}

\author{
Racheal Ddungu Mugabi ${ }^{1,3}$, Rosemary Nakijoba ${ }^{2,3}$, Deborah Sarah Nakirijja ${ }^{3 *}$, May Sengendo ${ }^{3,4}$ \\ ${ }^{1}$ Makerere University, College of Humanities and Social Sciences, School of Liberal and Performing Arts, \\ P. O. Box 7062 Kampala, Uganda \\ ${ }^{2}$ Ndejje University, Faculty of Social Sciences, Kampala, Uganda \\ ${ }^{3}$ Victoria University, Faculty of Humanities and Social Sciences, P. O. Box 30866 Kampala, Uganda. \\ ${ }^{4}$ Makerere University, School of Women and Gender Studies, P. O. Box 7062 Kampala, Uganda \\ *Corresponding author email: deborahsn1991@gmail.com
}

Received: 10 May 2021 / Revised: 21 August 2021 / Accepted: 09 September 2021 / Published: 27 October 2021

\begin{abstract}
A BST RACT
The aim of the article was to explore ways in which formal and non-formal skills development programmes can be improved for education continuity and employability of marginalised youth. This is attributed to the fact that coronavirus disease (COVID-19) with its related lockdowns is causing not only unprecedented disruption in the provision of skills, but also catalysed innovation in distance learning. A qualitative case study with some elements of action research, systematic inquiry and non-participant classroom observation with capability and empowerment theories supported the inquiries. Thematic analysis was used. Results reveal that while access to skills development was maintained in some spaces through a rapid shift to distance learning, the pre-existing social and digital divides deprived marginalized groups of continued learning and putting them behind schedule. Many institutions and learners lack operational distancelearning platforms, digital skills and devices. Save for the few exceptions, distance learning policies by the government have not yet been able to facilitate the acquisition of practical skills, which are critical components for the success of education and employability. Evidence points not only to pedagogical dimensions with educator's incompetence to provide a supportive environment, but also to designing structured educational resources versus the abundance of online resources, disruptions to assessment and certification, and a general decline in the quality of practical training causing demotivation among learners and educators. The general increased economic hardship has also increased the likelihood of marginalised youth dropping out of education. The study recommends a robust shift on how skills are delivered-shift to digital literacy and adoption to technology, forge national and regional public private partnerships to increase the availability of accessible distance learning solutions, allocate more financial resources, develop new training programmes by marrying curricula to real life working situations, assess and certify online for educational continuity and employability.
\end{abstract}

Keywords: Skills Improvement, Marginalised Youth, Uganda

\section{Introduction}

Globally, COVID-19 has posed particular challenges to skills development programmes (SDPs) which need urgent improvement. Most notably, it has set back progress in the achievement of Goal 4 of the Sustainable Development Goals (SDGs, 2015) to "ensure inclusive and equitable quality education and promote lifelong learning opportunities for all. The digital learning environments that most institutions had to rely on during closures do not work as well for practice-oriented learning-a core component of these programmes' instruction-as they do for academic learning (International Labour Organisation-ILO and World Bank, 2021; Green, 2021). Africa in particular has noticed that, while access to skills development was maintained in some spaces through a rapid shift to distance learning, the pre-existing social and digital divides deprived marginalized groups of continued learning and putting them behind schedule (African 
Union and African Union Development Agency, 2020; ILO and World Bank, 2021; UNICEF, 2020; United Nations Educational Scientific and Cultural Organizations -UNESCO, 2020; Tumwesige, 2020). Except for the few institutions, distance learning policies by the government (Ministry of Education and SportsMOES, 2020) have not yet been able to facilitate the acquisition of practical skills, which are critical components to solve education and employability challenges.

COVID-19 literatures on SDPs indicate challenges and call for an urgent need for improvement. These challenges include but not limited to; technological infrastructure concerns (electricity, internet, connectivity, and devices); limited staff capacity to support distance learning through quality pedagogical resources such as designing and developing learning content for online, offline, remote learning, student engagement and quality assurance; limited effective or user-friendly distance learning platforms; financial and educational resource constraints; disruptions to assessment and certification, and a general decline in the quality of training which has caused demotivation among learners and teachers (African Union, 2020; ILO and World Bank, 2021). The practical orientation has posed additional challenges especially the video and streamlining which require bigger data packages, and therefore more expensive (ILO and World Bank, 2021). However, video -learning would present an opportunity to use technology where physical access to the latest equipment may not be possible. Tumwesige (2020) findings in Uganda expose the parents' and learners' dissatisfaction of relevance and progression in lieu of alternative ways for their children to spend time and contribute to the family. The general increased economic hardship has also increased the likelihood of marginalised youth drop in access, affordability and eventually dropping out of education (UNESCO, 2020).

The closure of institutions with inconsistence reopening (UNESCO, 2020) has at least affected 1.5 billion learners in over 188 countries. The affected numbers do not take into account all those that are marginalized, disadvantaged or those invisible in the education system. Lockdowns in Uganda have affected at least 73,200 academic institutions, over 15,100,000 learners and 54,800 teachers (MoES, 2020). The first lockdown was declared on 24 March 2020 (Ministry of Health, 2020; Kawuki et al., 2020) to latter more two lockdowns ending on 30th July, 2021.

Uganda's MoES thus developed an education sector preparedness and response plan to solve educational challenges especially for institutions, learners, parents and the general public in May 2020. This education sector response plan was to be aligned to the health sector response plan. Currently, some of the standing measures include: setting up a coordination committee; issuing policy guidelines to all heads of schools; collecting contacts by District Education Officers (DEOs) from schools; develop standardized sessions under the National Curriculum Development Centre (NCDC); improve access to online resources; no extra fees to be charged as schools reopen; and working with local governments through DEOs and Heads of Schools to prepare learning through digital, online/offline materials, radio and television trainings. The above strategies were aimed at continuation of learning through 'virtual schools and distance education' while learners were at home (MoES, 2020). Distance learning was to continue even after the third lockdown was opened until vaccination. Without vaccine in Uganda for most citizens against COVID-19, the end of distance learning is uncertain, affecting re-opening of institutions, which could lead to a very disruptive stop-go period during recovery with opening and closing. COVID-19 thus threatens to reverse the years of educational progress in Uganda (UNESCO, 2020) where overwhelming challenges still remain. SDPs education has been previously approached from the lens of education sector as a whole during COVID-19 guidelines in Uganda (MoES, 2020). There is a disproportionate focus on how SDPs can be improved which has culminated into this study.

Studies have addressed COVID-19 concerns from several perspectives with limited studies on SDPs. These perspectives include but not limited to; eliciting the scope and possible interventions for the COVID-19 victims (Chinnayan, 2020), exploring the types of reactions people have been showing amid the pandemic from COVID-19 (Ahmed, 2020), evaluating Nigerian social media user perception on social distancing, lock obligatory and response satisfactory on the outbreak of COVID-19 pandemic (Olagunju et al., 2020) and the social implications of COVID-19 (Kulkarni and Lorenz, 2020) in other countries. 
Mugabi et al., Adv. J Social Sci.; Vol. 9, Issue 1, pp: 10-26, 2021

In order to address the dearth of information, the article explored the ways of how to improve formal and non-formal SDPs for marginalised youth, highlighting issues for which there is preliminary supporting data from graduates, learners', employers, parents, key informants and staff experiences. This was to ensure better preparedness, achieve the 2030 Agenda for SDG goal 4 with a resilient path (United Nations, 2015) and the National Development Plan agenda (2020-2025) on the theme of education and lifelong learning through skills development. The issues high lightened are not comprehensive, but rather a starting point to begin a long process to support the marginalised youth in the time of COVID-19 through skills development programmes.

\subsection{Why Skills Development?}

SDP purposes converge at the process of empowering learners through imparting knowledge and skills for employability. The diversion however, emerges at the focus taken by each study. Nuwagaba (2012) study revealed that skills development enhance employment, self-sustenance in the world of work for formal and informal employment. Bennel (1999) emphasized social inclusion and development of those excluded such as the marginalised youth and the unemployed youth. Other studies (Tukundane et al., 2015; MoES, 2011; UNESCO, 2012; 2012a) argument for SDPs is to increase marginalized youth's chances of entering into the labour market. Powell on the other hand goes ahead to introduce the idea of values and attitudes to improve the learners' life chances, "respect, self-confidence and personal pride" (Powel, 2012, p. 650). Kearns (2001a) recognizes the relevance of "Values and attitudes" to the economic success of knowledge economy (p.46). Yet Quisumbing (2001) supports the development of values and attitudes to build a culture of peace and democracy. SDPs are required for integration into the labour market (Adams, 2007; 11 African Progress Report, 2012; Kende-Robb, 2012; UNESCO, 2012a; 2012b; World Bank, 2006b). Eventually (MoES, 2011) studies reveal that SDPs are to furnish the badly required skills for employment and competences. Therefore (Africa Progress Report, 2012; Blaak et. al., 2013; BTVET, 2011; Sappa and Bonica, 2011; UNESCO, 2012b; Yassunaga, 2014) assume that SDPs can improve the quality of life of the marginalised youth. This comes in a milieu when Uganda is trying to provide SDPs, yet facing challenges that need improvement.

\subsection{Problem Statement}

COVID-19 has affected 1.5 billion learners in over 188 countries (UNESCO, 2020) with over 15,100,000 learners in Uganda (MoES, 2020). The digital learning environments that most institutions had to rely on during closures do not work as well for practice-oriented learning-a core component of these programmes' instruction-as they do for academic learning (ILO \& World Bank, 2021; Green, 2021). It is also clear that while access to skills development was maintained in some spaces through a rapid shift to distance learning, the pre-existing social and digital divides deprived marginalized groups of continued learning and putting them behind schedule (African Union, 2020; ILO and World Bank, 2021; UNICEF, 2020; UNESCO, 2020; Tumwesige, 2020). Except for the few institutions, distance learning policies by the government (MoES, 2020) have not yet been able to facilitate the acquisition of practical skills, which are critical components to solve education and employability challenges. Skills mismatch has thus persisted despite the MoES guidelines to continue with provision of skills development. This has led to employability challenges attributed not only to inappropriate, insufficient or poor-quality education, but also early school leaving. Skills mismatch hinders young people's chances to enter the labour market, national prosperity and development as envisioned by (BTVET, 2012; National Development Plan, 2020-2025; Uganda Vision 2040; Uganda Labour Market Profile, 2016). Formal and non-formal SDPs have a greater potential for getting to human conditions of the excluded, unemployed, poor, illiterate, and especially the ESLs (Grandstaff, 1978; NDP, 2015-2025; Tukundane \& Blaak, 2010; SGG 4; Tukundane, 2015). Unfortunately, many studies (African Union, 2020; Alzira et al, 2015; ILO \& World Bank, 2021; UBOS, 2016; UNESCO, 2020: Tukundane \& Blaak, 2010; Nampota, 2010) have stressed that SDPs have many challenges and/ or are rather poor and many areas require improvements. In this sense, it is relevant to explore how SDPs can 
be improved for educational continuity and employability of marginalised youth. To explore ways of improvement, the study employed a hybrid of capability approach and empowerment theories.

\section{Theoretical Considerations}

The theoretical considerations are informed by Jarvis (2006), Freire (2005), Sen (2001) and Nussbaum (2011). The study moves from a neo-liberal approach which promotes economic liberalization to a more humane interpretation of development which focuses on the quality of life. Amartya Sen (2001), Indian economist awarded with the noble prize in economic sciences in 1998, is one of the main theorists influencing the move of the development paradigm towards humane broad interpretation of development and the quality of life. He introduced capability approach theory into the interpretation of development. He stresses that, "development can be achieved when individuals gain economic opportunities, political freedoms, social facilities, transparency guarantees and protective security" (p. 22). Within the capability approach, the emphasis of applicability to this study is on capabilities, functioning's, and agency of an individual. "Capabilities are the opportunities or choices that one values. Functioning's are what one is able to do with the opportunities or the choices" at his/her disposal. Agency is a person's ability to pursue and realize goals she/he values and has a reason to value (also in Robeyns, 2003, p. 100-103). Capabilities are not ends in themselves, but together with associated freedoms, they are means to develop people's wellbeing and quality of life (Sen, 2004). This implies that, development is not only implemented by governments and development agencies, but also individuals can become agents of development (Sen, 2001). As Sen in previous studies argues ... in development activities "the people have to be seen ... as being actively involved... given the opportunity... in shaping their own destiny, and not just as passive recipients of the fruits of cunning development programmes" (Sen, 1999, p. 53). Any interventions should thus be assessed in terms of capabilities and policies designed to promote capabilities. The researchers thus argue that, educators at that level would be challenged to find appropriate methods which can help participants to be more active and participative in the wider environment of their individual and collective life. Therefore, this emphasizes the role of educators as facilitators which forms the basis of Jarvis empowerment ideology.

Jarvis Peter (2006), a leading and original theorist of learning is also a proponent of development paradigms towards broad human interpretation of development. He stresses that; i) the world is continuously changing; therefore, education and training need to act in response to these changes within societies; ii) educators to act not only as facilitators, but also “...support learners to ...learn the subject and achieve their potential" (p. 25); iii) facilitation of knowledge to move from the previous provision of "static knowledge to a dialogical relationship where knowledge is co-created" (p. 99). Educators as facilitators thus informs the foundation concept of Freire's pedagogy in which participative learning is at the core.

Paul Freire (2005), a Brazilian educationist and a philosopher recognizes; i) the empowering character of dialogue where "actors cooperate in perceiving the same cognizable object" (72); ii) rejects banking or depositing education in which learners are receptacles of knowledge and thus advocate for learner-centered learning where an educator is a facilitator, and not a narrator; iii) education to empower learners, to be able to recreate knowledge, rather than passively repeating the acquired information; iv) besides psychological change and opportunities, reflective action is essential for true development. Participative learning and empowerment in this study context, can be viewed as a way to improve the self-esteem of participants, as many of them have been excluded from education and the labour market. The role of Nussbaum's ideology (2011) of universalizing capabilities within the cultural contexts of people enshrined as a human right blends the theoretical framework. In so doing, data collection took a qualitative exploratory approach as explained in the methodology.

\section{Methodology}

This was a qualitative exploratory case study with some elements of action research applied in six government training institutions. Qualitative stand supports in understanding skills development for 
Mugabi et al., Adv. J Social Sci.; Vol. 9, Issue 1, pp: 10-26, 2021

marginalised youth within context-specific settings (Golafshani, 2003). McGrath and Lugg (2012) advice that research on vocational education should use a "variety of methods" (p.8) including qualitative methods yet, Powell (2012) emphasizes the importance of listening to the side-lined voices of learners in research. This is why McGrath (2012b) proposed 'a shifting of the focus of training research away from the domination of the technocrats view that privileges a focus on systems and institutions and their efficiency towards more humanistic approaches that place individuals at the heart of research as subjects as well as objects" (p.630). Ritchie and Lewis (2008) summarizes that; "qualitative research emphasizes and values human interpretative aspects of knowing about the social world and the significance of the investigator's own interpretation and understanding of the phenomena being studied" (p.7).

Action research for this study, emphasized participatory and collaborative ways of knowledge production and encouraged participants to act as "collaborators in the study rather than being subjects of it" (Descombe, 2003, p. 74). Action research from Koshy (2010) perspective is "an inquiry where participants and researchers co-generate knowledge through a collaborative communicative process" (p.21). In this regard, a WhatsApp feedback group for continuous discussion was created for all the six case study training institutions to follow up on the participatory nature of the action research approach. The main purpose was to gain insight into the participant's reflection and allow their collaboration during the study process. Other support design include; case study. Multiple level case studies were involved in this research including: i) Uganda is used as a case study to illustrate the location of the study and interaction amongst institutions, skills and labour market; ii) The six institutions chosen represent case studies of particular skills development programmes institutions; iii) formal and non-formal SDPs across the primary, secondary and services sector and iv) those interviewed are themselves micro-level case studies. Advantages include: i) the use of a variety of data collection techniques allows multiple triangulation to provide a rich depth of data (Bryman, 2001; Hakim, 2012; Stake, 1998); ii) provides room for comparison and contrasting to occur; iii) the confidence in the general significance and robustness of research findings increase with more case studies (Sudman, 1976 cited in Hakim, 2012). However, the limitation include; i) results can be strongly shaped by the interests, or perspective of the researcher (Hakim, 2012; Reinharz, 1997). Moreover, this method has been criticized for its lack of rigour and generalizability (Bryman, 2001). A cross check was used through the use of multiple tools (interviews, focus groups and observation). Since different information arises from different tools, a more holistic view was obtained overall.

A total sample of 181 people participated through purposive sampling "based on a specific purpose rather than randomly" (Tashakkori \& Teddlie, 2003a, p. 713). With the support of the initial workshop, 2 director of studies and 4 principals for the different institutions, we purposively selected the sample based on the criterion that; i) the respondents possess knowledge, experience in relation to the topic and would give valuable contributions, ii) a government institution that provides both formal and non-formal SDPs with information access in two different milieu of urban and rural areas of central Uganda where the institutions are located. In-depth interviews constituted 59 respondents with 24 graduates, 12 learners; 6 employers, 7 Institutional staff, 6 parents; 4 key informants with the Deputy Director-Directorate of Industrial Training, Director of Uganda Association of Private Institutions, Executive Secretary-Change Education Attitude Uganda and the Commissioner of BTVET Uganda. Focus group discussions consisted of 24 respondents including; 12 graduates with separate groups of male and female, 6 employers and 6 institutional staff. WhatsApp feedback group consisted of 98 participants. The study was executed in four steps to support data collection. This was through: observation of professional practices, critical reflection, systematic inquiry and planning for action (Castello, 2007, p.11).

Systematic inquiry was informed by the first workshop before the lockdown. This workshop focused on collective reflection about SDPs improvement. Participants were organized in four small groups composed of separate male and female groups of graduates, 6 employers and 6 institutional staff. The objective was to collect suggestions/ or raise a debate and eventually come up with ways of improvement from the perceptions of different actors. The participants wrote down their contributions, which were collectively discussed in the workshop and later evaluated in the WhatsApp feedback group. 
WhatsApp feedback group was established to allow critical collective and participatory reflection during the different steps of the study process. In the feedback group, same respondents interviewed who had phones with WhatsApp numbers were involved. The study faced a challenge of locating some of the participants who received skills and already in the labour market. This is because some of them changed or lost their telephone contacts and thus snow ball where one alumnus would lead us to another was employed. 2018 cohort were selected because 2 or more years was enough time for one to have found employment or started a business and also have enough reasons why neither of the two has not happened.

Non-participant institutional observations was used to understand the characteristics of the teachinglearning activities, the role of educators and learners during the training process, the equipments or tools used against the number of students, presence of infrastructure or workshops and access of participants. This was done to verify information received from the participants who received skills and already in the labour market, learners, educators and employers.

The cases of SDPs were formal and non-formal. Non-formal SDPs are normally 3 months for one skill. This is because the intention of the skills programme creation is to develop skills in a specific trade designed for non-education or anyone who is in need of a specific skill. If one wishes to get more skills, they can upgrade to 6 or 9 months done with in the environment of an established institution (BTVET, 2012; MoES, 2012; UBOS, 2010; UNESCO-IBE, 2010). Formal SDPs are of different levels with their equivalence. Primary 7 leavers: formal technical schools and institutions (3 years); Uganda Vocational Qualifications Framework (UVQF) level 1 and awarded a certificate of Uganda junior certificate. One can also upgrade to formal technical institutes for craftsman level 1 ( 2 years): UVQF -level 2 and a certificate of craft certificate part 1 is awarded. From that level, one can upgrade to formal technical institutes: UVQF level 3(one more year); and awarded a master craft/ advanced craft part 11 certificate. From that level, one can upgrade to technical colleges: (2 years); UVQF level 4 and awarded a certificate or a diploma /instructor (MoES, 2012). Permission to carry out research was obtained from the National Council of Higher Education, institutions involved, employers, skills development programmes graduates, learners and parents. Thematic analysis was employed (Liamputtong \& Ezzy, 2005) to come up with ways of SDPs improvement.

\section{Results and Discussions}

In reference to interviews, WhatsApp feedback group, non-participant observations and focus group discussions, COVID-19 is presenting different challenges. These have to be addressed to allow access, participation and provision, technological infrastructure and platform development, build digital skills and provide devices for both educators and learners, develop new methodologies and pedagogical approaches. Experiences also insisted on forging national and regional public private partnerships to increase the availability of accessible distance learning solutions, allocate more financial resources, develop new training resources by marrying curricula to real life working situations, assess and certify online for educational continuity and employability. Analysis was based on themes as they emerged from the data for SDPs improvement.

\subsection{Access, Participation and Provision}

Key informant interviews reveal that; effects of COVID-19 on access, participation and provision of SDPs started from the onset of complete closure of training institutions in the country. The presidents' advisory directive of lockdown and stay at home was a mitigating measure to stop the spread of COVID-19. At least all respondents remembered the $24^{\text {th }}$ day of March, 2020 when the president closed down institutions of learning and advised distance learning. Principal [1] noted that "the government policy guidelines on COVID-19 were and are still very stringent in its measures given that skills development education require practical classes than theoretical ones which can be done on line or at distance education which need to be eased". The implication is that the learners have been constrained by institutional closure denying them an opportunity to participate in their right to lifelong learning (SDG 4; 2015; NDP 2020-2025). 
Mugabi et al., Adv. J Social Sci.; Vol. 9, Issue 1, pp: 10-26, 2021

The results also fall short of development as espoused by (Sen, 2001; Robeyns, 2003) where individuals have to be seen... as being actively involved...given the opportunity ...to shape their own destiny and not passive recipients of development programmes as seen with the MoES (2020) COVID-19 policy guidelines. Key stakeholders have not been consulted on the best ways of delivering education at different levels. Staff, learners' interviews and WhatsApp group discussions insisted that; while distance learning is being explored and exploited by some institutions, it cannot replace face to face classes given a particular emphasis of work-based learning and acquisition of practical skills. The learners and staff are thus unable to ensure continuity of practical learning. Key informants explained that institutions were closed with a lack of coordinated response to respond to the challenge of incorporating work-based learning in distance learning. Principal [2] lamented that;

While closure of institutions seemed to be a short term crisis response, it may not be adequate in the event of prolonged lockdowns until vaccination. Some of the practical lessons taught at the beginning of the year might be forgotten at the end of the year and so staff have to start afresh yet, under the pressure of completion of curricula. Institutions in the end will produce students with low skills or skills mismatch.

Principals and staff are uncertain about the current school year and entry into the labour market which has caused anxiety and confusion among learners and this has affected their willingness to continue studying. Closure of institutions has delayed hands-on practical experiences which in turn has interrupted the learning process and it is a demotivating factor for students. Obstacles to continuity in the provision of training to learners appeared at the onset of the crisis as well. Principal [3] during the interview noted a "swift shift towards remote training measures to ensure continuity of education is in itself a challenge". Key informant [3] however noted the unpreparedness of training institutions to face this challenge. All interviews with principals and staff reveal a lack of motivation posed by the swift disruption of the face-to-face classes and the challenge of transitioning to distance learning modalities which has increased workload for staff. It is reported by staff that transition is not easy. Principals, staff, learners, parents and employers explained that they were not adequately prepared for this abrupt transition to remote learning, given the lack of necessary skills and infrastructure to accommodate distance training and learning methods.

Forging national and regional public private partnerships to increase the availability of accessible distance learning solutions such as work-integrated learning experiences since the government had started easing industrial related work was urgently proposed by the [key informant 1 and WhatsApp feedback group]. This was to support both the national and international students' access practical skills for their programme's continuity and assessment. Moreover (Indabawa and Mpofu, 2006) support learners to practice what they have studied through income generating activities. Public- private partnerships just like previous studies (African Union, 2020; Indabawa and Mpofu, 2006) amongst government, telecommunication companies and technology providers were also proposed by all respondents to build not only the base for policy development amongst the key stakeholders, but also for skills accessibility, participation and provision. This was attributed to a general lack of effective and user-friendly distance learning platforms by respondents. WhatsApp group discussion agreed on the lack of quality remote learning platforms which depends on the functionality of the learning platform and tools through which programmes are delivered. That is why Jarvis (2006) in his theory of learning advised that the world is changing therefore educators and training need to act in response to these challenges in society as is this case COVID-19.

Participation in SDPs is also stigmatised and viewed with a negative social perception by the public: a second-class education; meant for socially excluded and economically underprivileged sections of the populace as explained by key informant [3]. This is reinforced by previous studies (Jjuuko 2012; Openjuru, 2010; Tukundane 2015; UNESCO, 2010). The implication is that; i) some parents might not encourage their children to enroll, and ii) damages participants self-esteem and confidence who are already magnalised not only by educational exclusion, but also in the labour market. It is also clear that, public awareness has not been created to address this popular negative perception. Certainly, many of the programme 
participants have diverted their efforts from mastering the skills, to studying for passing the exams. This is because, some of the learners interviewed saw these programmes as a ladder to enroll for the highly needed diplomas to fulfill not only their self-image, but also to deal with stigma as they struggle to compete with those of mainstream formal education. The story of negative perception however, does not necessarily feature among the graduates. All graduates hold a positive perception about the purpose of the programmes once employment opportunities are available. They consider the programmes as a path way to the world of work. Their perceived relevance stems from learning income generating activities especially during faceto-face classes or at work integrated learning placements, which are useful alternatives in the context of Uganda characterized by massive employment concerns. Practical experiences to enable learner's access and participate in SDPs has been constrained by lack of technical infrastructure.

\subsection{Technical Infrastructure and Platforms}

Digital learning has been an obvious solution in the context of national lockdown regulations and social distancing for learners as discussed in WhatsApp group. Most of the narratives were about technological challenges. Similar studies in Africa and Italy reinforce the results of technological challenges (African Union, 2020). Moreover, many young people especially in rural areas do not have access to internet, or devices which serves to perpetuate and further amplify the digital inequality and widen the existing gap.

Lack of the necessary equipments by learners required to complete tasks related to their training and educational programmes such as $\mathrm{Wi}-\mathrm{Fi}$, tablet or computer was common from all respondents. Learners on WhatsApp group clearly indicated that although distance learning is on-going, some of their classmates have already dropped out due to lack of access and affordability of distance learning such as digital devices, internet, electricity, lack of skills to learn from such platforms and additional payment of fees at every extension of their studies. A similar recent study in UK London and Estonia by Fernando et al cited in African Union (2020) indicate that internet has been down a lot. Respondents have called on telecommunications companies, technology providers and MoES to provide free access to educational websites to support online training and learning. This is reinforced by recent studies (African Union, 2020; ILO-World Bank, 2020; UNESCO, 2020). They have also called for public private partnerships for work integrated learning to benefit from practical part, assessment purposes and certification.

The digital divide indicatively between the urban and rural communities was highlighted as a severe challenge and deepening the already existing inequalities in Uganda. Principal [2] noted that;

Despite the government provision of continued learning on radios and televisions by learners in primary and secondary education, SDPs were a forgotten programme regarding remote training via online platforms...In any case, most of our learners are in rural communities and would have been unable to benefit from such programmes given the lack of connectivity or absence of devices like computers or digital equipments and Television sets, yet with no electricity or internet connectivity.

Radio and television adoption were proposed by all respondents for continued learning and would be an opportunity for transferring practical skills especially where physical access is not possible. However, they bring with them big usage of data challenges which pushes many to fall out. One WhatsApp response with a laughing emoji noted that "coping with increased data usage given the taxes imposed on it by the government adds salt to the wound of the crisis usually borne by the learners and staff or institutions".

WhatsApp group discussion explained the digital divide between rural and urban communities which has exacerbated inequalities in Uganda. Director [1] of studies insisted that "there is an ongoing deepening inequality among learners in terms of access to and quality of training in rural and urban due to either financial constraints to afford/buy them or lack of skills to use them". Staff in the focus group and learners on WhatsApp responses attributed the deepening inequalities challenge to a general lack of technological infrastructure; on and off electricity supply in some communities; slow, unstable, low bandwidth or lack of internet connectivity and devices. Staff in focus group discussions agreed that they are finding challenges or not retooled regarding such tools as zoom, google meet and skype to communicate or demonstrate to 
Mugabi et al., Adv. J Social Sci.; Vol. 9, Issue 1, pp: 10-26, 2021

learners since most of their trainings are practical. Staff [4] lamented that "it is hard to adopt to new technologies and move learning to a virtual environment". In Rural settings however, Staff [3] noted that;

There is a cultural reluctance to embrace distance or online learning in the field of skills development especially given that many women trainers and learners prefer physical classes or have no skills on how to use the devices.

Director of studies [2] insist that while COVID-19 has posed severe challenges, there was already challenges of mechanically damaged, old, outdated and/ or lack of equipments. He quoted that;

My class has one old vehicle against 30 students. Students are supposed to assemble, trouble shoot a problem, rectify it, and then test for its functionality - but apparently; they are not adequately equipped with these industrially required skills in the time of social distancing.

Through observations; the training equipments of some institutions were few, outdated, mechanically damaged, impaired and/ or inadequate for the number of enrolled students and most of the required infrastructure were much wanting. Apparently, graduates maintain that most of the institutional staff were not equipped with modern market skills to transfer to their students and prepare them according to the demands of the labour market both locally and globally. Quality products require better qualified programme instructors and curricula that meet the demands of the labour market. Such institutional challenges in Uganda somewhat compromised the achievement of the intended programme objectives. This is reinforced by previous studies (Alzira et al, 2015; Castro, 1997; Fluitman, 1998; Greirson, 1996; Harper, 1996; ILO, 1998a; Sanyal, 1996; Tukundane, 2015). This lack of crucial training equipments, facilities and other incentives hinder SDP graduates to quality performance in the labour market. Although the SDPs have been perceived with positive relevance, it lacks sustainability, seems obsolete and unappreciated by the employers' responses.

It is therefore imperative to have coordinated and systematic interventions to address digital divide for marginalised youth to benefit from the right to life- long learning through SDPs. In this regard, SDPs agenda need to be taken into broader context of other measures that MoES (2020) is putting in place as a response to the crisis as is the case for primary and secondary education. Key informant [2] however noted that despite the negative challenges, COVID-19 has simply accelerated the transition which was already underway towards the digitalization of training and the importance of developing digital skills with a focus on learners and educators. Partnerships with telecommunication companies to provide free access to educational websites, technology providers and MoES has been cited by all respondents to support continued training and learning of both educators and learners respectively. Principal [1] cited digital learning platforms which could be built with such partnerships. Victoria University in Uganda was cited as one of the high institutions of learning that has continued to provide education during the lock down which has provided low costs for accessibility of their V-class for training, assessment and certification as a new pedagogical approach.

\subsection{Develop New Methodologies and Pedagogical Approaches}

Pedagogical resources to support distance learning and/or remote training at the national level as other levels of education like primary and secondary was proposed by principals' interviews and staff discussions. Staff indicate that some of the televisions are fully programmed and so skills training might have to lobby through MoES. The content proposed by principals and staff is supposed to fit the needs of the learners and connect to work life as suggested by other studies (Waniha, 2008). Lim et al. (2012) therefore advises that "...receiving skills cannot be reduced to merely an investment for securing a job; rather, it should have wider aims such as emancipation of the learners to seek out a livelihood" (p.665). In this way, skills development contributes to the improvement of young people's life choices, human development and the development of the wider society. Some aspects of African content mentioned were; literacy, numeracy, vocational skills and skills life (Minnis, 2004; Nampota, 2010; Sen, 2001; World Education Forum, 2000). This study however brings in new aspects of technological skills for both educators and learners on addition to what previous studies are proposing. At the individual level, respondents propose content which should 
help learners to acquire marketable skills, business skills, decision making skills, knowledge to make informed decisions, social skills to manage social support, awareness of one's position and rights in society, strong self-esteem and assertiveness (Blaak e $t$ al., 2013, p. 95). In general, formal and non-formal SDPs should not only provide knowledge and skills, but should also empower participants. Empowerment highlights education which emphasizes, "ownership of the learning process and learning to acquire the skills to actively promote changes, rather than becoming passive recipients of top-down initiatives" (Preece, 2009, p. 66). While teachers are expected to act as coaches by giving systematic feedback to learners, the choice of teaching methods that fit the learners is very important to stimulate learners' responsibility such adoption to online pedagogical methodologies. Administrative strategies; such as, control of the training activities by monitoring is vital to prevent absenteeism and drop out (Nampota, 2010). Preferably, use of mother tongue is vital especially for basic level education discussed in this study as in previous studies (World Education Forum, 2000).

A pool and share open educational resources (OERs) were one of the enablers to access, use, adaptation and provision of open education resources from respondent's interviews. This was attributed to budget, time and lack of staff capacity to design and develop learning content online and offline which was not available in a short time. Many learners and staff were not happy with the lack of appropriate platforms and tools that deprive students of an effective common space of interaction to learn and work which may eventually lead to a less effective learning experience. Principals are worried about a negative attitude to change in teaching methods as some staff were not used to distance learning modalities. Staff, learners and institutions were not prepared to adopt to distance learning modalities as a consequence of low-level skills. African Union study and African Union Development Agency (2020) reveals that respondents from different African countries recommended OERS. Staff and principals suggested a one term period of catching up and plan for measures to curb infections, retooling educators to develop online educational resources, adopt to new technology and use of online platforms, as they also share OERs. Supporting educators' capacity in pedagogical methodologies especially in continuous retooling in content development, pedagogical skills needed for integrating ICT into teaching and learning to create a supportive environment to motivate educators and learners was highly recommended by respondents as advised in empowerment theory of Freire's (2005) pedagogy.

Teacher-centred style of teaching was yet another pedagogical challenge. Employer [1] lamented that in our services industry, "competences are not developed with a lot of theoretical courses". Moreover, graduates and learners on WhatsApp group are bored of top-down teacher-centered style of training. Freire (2005) considers this type of education as 'narrative', in which the learners are repositories of the learning content. The teacher-centered style of training promotes learners' passivity and lack of reflective thinking. In the actual context of this daily dramatic change, SDPs need to stimulate peoples' functional skills to actively engage in different spheres of their lives for an improved quality of life (Sen, 2001). This thus implies an urgent need for profound and / or reflective changes in the roles of both educators and learners in SDPs. Jarvis (2006) for example advises that educators must help learners to learn and achieve their potential. Flexibility and learner-centeredness should be one of the basic principles in skills development. Other commentators on the same subject in Africa such as King, argue that the scheme "did not result in either appropriate training or relevant work experience for large numbers of young people who participated" (King, 1996, p. 43). He informs us that, in particular, non-formal training periods are too short to overcome basic skills deficiencies. That is why trainability is an important concern especially in the non-formal programmes assessed. It is not to deny that the marginalised youth are heterogeneous leading to day today challenges for practitioners concerning the language of instruction. Illiteracy among the participants significantly lowers the trainability of participants (ILO, 1997), as indicated in a similar study in southern Asia. Therefore, often but not always said, it is not surprising that, the present study reveals graduates claiming unreceptive local and international labour market, underemployment and unemployment as noted in other countries (Campbell \& Ahmed, 2012). With an inadequate number of jobs in the formal economy and as unemployment is not an option in the absence of a social protection system, work in the informal 
Mugabi et al., Adv. J Social Sci.; Vol. 9, Issue 1, pp: 10-26, 2021

economy is the option for the majority of workers in Uganda (UBOS, 2013; UBOS \& UNHS, 2005/6; $2009 / 10)$. This probably explains why graduates are claiming labour underutilization and underemployment in Uganda.

SDPs are to meet the skills needs for all in an effective and equitable manner (BTVET, 2012). However, the two cases have been criticized for being ineffectual. Moreover, marginalised youth attend formal and non-formal SDPs to acquire qualifications that could give them access to high paying technical jobs. This is because the skills programmes are to prepare people to become productively employed especially in informal sectors (ILO, 1998). These skills programs are claimed by respondents to have neither the capacity in terms of training nor the incentives to re-orient themselves to support the marginalised youth. The SDPs inadquance to adjust themselves is also universal. Latin America- which has the best record for providing training has been criticized for long delays by government in formulating strategies for the informal sector (CINTERFOR, 1998). Claudio de Moura Castro is even less confident: "Solid training institutions failed to adjust and the misfit between supply and demand became endemic" (Castro, 1996, p. 2). For Uganda, studies have given little attention and little devotion to analyze the various constraints that have prevented any such reorientation to occur. Even more and more serious, few, if any, commentators are prepared to say just exactly what this reorientation should entail. The result thus has been a vague and, in most cases, rather sterile debate which has lost any real sense of purpose and direction since it was first initiated over a decade ago even all over the world. The two cases seem to direct the current challenges at the implementation level (training) which latter affects their employability and the general performance in the labour market.

The challenge in training is the failure of SDPs to have appreciable and sustained impact on livelihoods of the participants. This lack of impact is correlated to the poor quality and/ or inadequate infrastructure and some instructors who are inadequately trained and demotivated to utilize the skills and knowledge they acquired due to a variety of economic and social constraints. Whereas most of the trainers are graduates of vocational institutes, or polytechnics, there is a missing link of special needs trainers, modern practical and pedagogical experience of staff. This is because most of the magnalised youth are not only drop outs, but also marginalised in the labour market, with no sense of self-esteem or worth and would only be supported by such whole round special trainers. Generally, the instructors had their own challenges that compromise their performance. Of all the staff that we interacted with, none had kind words for the SDPs management systems in place due to non- payment. Staff sincerely indicated how the crisis has thrown light on their inability to develop online learning resources in a short time. Principal [3] noted that;

The lack of staff capacity has resulted into difficulties with learner's engagement and quality assurance in distance or remote learning...motivation of students in their internship levels with emphasis on practical activities has also been affected. Many graduates thus claim unreceptive local and international labour market, underemployment and unemployment accompanied with low payment worsening their financial status.

\subsection{Financial Resource Mobilisation}

Respondents recommend financial resource mobilization not only for responding to COVID-19 pandemic, but also for long term positive impacts in creating equitable and effective learning environment for all citizens. This is reinforced by the recent studies (UNESCO, 2020; Tumwesige, 2020; Livia et al., 2021) in Uganda that reveal that COVID-19 presented itself with income losses as families consider opportunity cost of education. Financial resource constraints in form of cash flow and/ or financial viability was noted by all respondents, especially in small institutions. This was attributed to the unexpected loss of income from different sources such as tuition fees from students, government and the income-earning activities of institution centres. WhatsApp group discussions noted that learning has become a burden since the lockdown given the financial hardships in the country. Principal [1] shared his experience that;

Parents are unable to pay fees attributed to the economic hardships in the country thus many learners are dropping out... This has thus constrained our ability to invest time and money to pay 
trainers' salaries and allowances to design distance learning resources and build distance learning infrastructure.

Such voices as "I have missed my salary for the last three months...no incentives for houses have constrained me to effectively deliver..." explains the mystery of instructor's failure to do their work effectively. Staff [2] clearly emphasised that;

The economy will go down in the next 5 years...for not mastering employable skills competitive for the labour market... and will thus end up hiring people from outside the country instead of our own...This is also because many of the learners are illiterate and can only be instructed in local languages which also poses a problem to instructional design of resources.

Limited funding from the government mentioned by key informants compared to not as exactly as lack of public finance (UNESCO, 2013) came out strong as one of the major constraints to appropriate skills development. Whereas funding in the education sector has increased from $1.416 .3 \mathrm{bn}$ (14.7 percent), to 1.624.6bn (15.2 percent) financial year 2012/2013, skills programmes only take 6.5 percent out of the total share (MoES, 2012). Discussing with the deputy director of DIT at the preliminary stages of writing up the chapter, he mentioned that; low funding levels has not only marginalised skills programmes (unable to improve skills acquisition), but has also resulted into the present poor infrastructure status, poor motivation of trainers, dead end to nature of most courses, poor data generation, utilization and dissemination which is still a challenge and lack of research involvement by academicians. Familiar arguments were noted during the study by key informants, graduates and focus groups. The story is not exactly the same as in many SubSaharan African countries, but some claim low and delayed resource availability (Godfrey, 1997). While government facilitation is limited, institutions claim fees from students who are privately sponsored. Fees collection is however, so low to be able to equip the workshops with modern tools required in the dynamic labour market. SDPs policies and requisite finance mobilization must thus be integral to the recovery plan of improvement.

Learners also noted that although the cost of training is non-existent for government sponsored students, they still have to pay for digital infrastructure expenses which pulls out many poor learners. Overall, nonformal skills programmes manage to reach out to the economically disadvantaged youth because of nonpayment of school fees with the support from the government (BTVET, 2012), yet cheaper and affordable for those who pay. Contradictory voices of double costing were however, heard such staff [3]; "through fraudent dubious activities...the money ends up in the pockets of the administrators". [A common word used by respondents was institutional corruption]. Key informant [3] had similar sentiments that; "There is a general problem of double-costing. Administrators get students from formal programmes and put them to the non-formal programmes. The money meant to facilitate these students ends up in their pockets". Fees drive away the poorest. Training therefore intended for the unemployed is invariably "captured" by better off people. The costs of training will thus hinder some students to enroll. Costs of training in SDPs as proposed by all respondents should be as low as possible through partnerships which is reinforced by the recent study of African Union (2020). This thus boosts the shared ownership between the government and the community to ensure "attendance and the provision of teaching and learning resources" (Nampota, 2010, p.238). Alzira (2015) is in agreement with Nampota regarding shared ownership between government and communities. The study thus recommends counselling and guidance for the health of the participants. Guidance and counselling are essential on educational mental, physical and career issues (Conen \& Rutten, 2003; Waniha, 2008).

\subsection{Assessment and Certification}

Formative and summative assessment of students, and certification were postponed or cancelled due to lockdowns. While the government has not yet guided on assessment, principals and staff interviews suggest a common way of building blended assessment platforms with online and face to face assessments through social distance approach until things get back to normal. WhatsApp group discussion suggested a work- 
Mugabi et al., Adv. J Social Sci.; Vol. 9, Issue 1, pp: 10-26, 2021

integrated learning practice which could improve assessment and certification since the employers would assess the practical skills while the institutions would assess the theoretical part of the programmes online. Delayed monitoring and assessment cited as one of the challenges in the programs. This has led to failure for some students to be assessed and certified as they leave for other parts of the world after training. They thus can hardly be employed without certificates. The delayed assessment implication could be: (i) aggravated corruption by institutional heads, an evil that was also re-mentioned by many as being one of the reasons behind poor performance of the programmes. The little funds allocated for assessment end up being misused by accounting officers, who also create other unscrupulous avenues through which they can ill-enrich themselves as mentioned in the focus groups. There is a strong feeling in this study, that the government financial provisions are increasingly socially wasted and ultimately dysfunctional (Bennel, 1999). SDPs have ostensibly failed to meet the skills required by the labour market, leading to questioning of the relevance of SDPs in the labour market. Despite the concerted efforts of SDPs through government funding, the impact of SDPs training has been minimal.

Previous studies in Uganda by Uganda labour market profile (2016), claim that skills programmes offer limited skills for the modern labour market that is why the government introduced a strategic plan to guide the improvement of the skills programmes. However, after a couple of years of implementing the policy, low significant changes have been realized. The story is not any better in developed countries (Lalonde, 1996). It is also noted that; few training schemes for self-employment have worked. In his submission to the G7 Employment Conference, the Director-General of the ILO noted that; "The economic and social returns to standardized labour market training measures for vulnerable groups is low" (ILO, 1997, p. 4).

Today's labour market demands soft skills which most of staff and learners or graduates do not have. Seemingly, the requisite skills are under skilled by the SDPs; and as a consequence, the market systematically rejects their graduates. This challenge threatens the sustainability of the programmes as they gradually lose public confidence. Lim et al. (2012) cited in Tukundane (2015) warns us of a risk of "training for yesterday's skills that will no longer be needed in tomorrow's work" (p.102). It was not surprising that an employer owning a medium sized carpentry business commented that Parents were not going to continue taking their children to programmes that do not guarantee them a livelihood because they do not possess employable skills. If the government does not move rather faster to fix this dilemma through technology innovation, the programmes will eventually lose value and collapse.

Regardless of the training challenges, WhatsApp feedback group discussed that; SDPs to some extent attempt to improve not only the labour market opportunities, but also the quality of life of the magnalised youth including; (i) self-image is rebuilt from 'academic failures' to qualified professionals with certificates; (ii) earn a living especially those who have found employment or self-employment, and their lives would have been worse without skills; (iii) SDPs are a pathway for further education such as the commonly desired diplomas especially those in formal SDPs; (v) meet their basic need although some are involved in casual labour or in subsistence agriculture. Another argument on WhatsApp group however noted that, some have found themselves in informal sector with low pay, poor working conditions, double shifts (day and night) for more pay. It is unfortunate they lack start -up capital to start their own business/ enterprises. Through observations however, graduate [5] was spotted at the construction site coupled with a feeling of personal pride with a middle age youth voice and shining eyes as a sign of satisfaction was evident. That is why, Powell (2012), concluded that skills programme should build respect, self-confidence and personal pride of participants. It reduces stigma attached to both educational exclusion and eventually the labour market.

\section{Conclusion}

The purpose of the study was to gain insights on how to improve SDPs for magnalised youth in Uganda for education continuity and employability. Results reveal that while access to skills development was maintained in some spaces through a rapid shift to distance learning, the pre-existing social and digital divides deprived some marginalized groups of continued learning and putting them behind schedule. Many 
institutions and learners lack operational distance-learning platforms, digital skills and devices. Save for the few exceptions, distance learning policies by the government have not yet been able to facilitate the acquisition of practical skills, which are critical components for the success of education and employability. Evidence points not only to pedagogical dimensions with educator's incompetence to provide a supportive environment, but also to designing structured educational resources versus the abundance of online resources, disruptions to assessment and certification, and a general decline in the quality of practical training causing demotivation among learners and educators. The general increased economic hardship has also increased the likelihood of marginalised youth dropping out of education. The researchers through observations; noticed a very strong correlation between SDPs participants without proper training tending to experience persistent long-term scar effects of early phases of unemployment and a more vulnerable labor market position. There is thus a thread for example linking proper training to determining the chance of a successful transition into work. Despite of the unfulfilled obligations by some of the providing SDPs in a bid to understand and align the skills, the labour market indicators locally and internationally can be explored more for improvement. The study thus depicts that; institutional settings and public policies play a prominent role in influencing the transition from a marginalised position to skills development and eventually to employment. Promoting a successful transition not only prevents long-term negative consequences of early phases of youth employment concerns, but it also enhances individual professional careers, increased earnings for those who can find employment, economic productivity and social cohesion. The study recommends a robust paradigm shift on how SDPs are delivered-shift to digital literacy and adoption to technology, forge national and regional public private partnerships to increase the availability of accessible distance learning placements, allocate more financial resources, develop new training programmes by marrying curricula to real life working situations, a blended assessment and certification of both online and face to face with social distancing in theory by educators and practical by partners for educational continuity and employability.

\section{Declarations}

\subsection{Acknowledgements}

We thank all respondents with their support in obtaining primary data and for their inputs that greatly improved the manuscript and for sharing their cases with us during the course of this study.

\subsection{Competing Interests}

The authors declared that no conflict of interest exist in publication of this work.

\subsection{Informed Consent}

Consent of respondents was sought from each respondent prior to engagement so that they do not feel coerced. National Council of Science and Technology provided the initial letter allowing the study to take place. An ethical form was signed and presented to every respondent and administrator at the time of the interview. Thus, all information given by respondents was handled with confidentiality.

\section{How to Cite this Article:}

Mugabi, R. D., Nakijoba, R., Nakirijja, D. S., \& Sengendo, M. (2021). Formal and Non-formal Skills Improvement for the Marginalised Youth in Uganda. Advanced Journal of Social Science, 9(1), 10-26. https://doi.org/10.21467/ajss.9.1.10-26

\section{References}

Adams, A.V. (2007). The role of youth skills development in the transition to work: A global review. Washington, DC: The World Bank. Adams, A.V. (2011). The role of skills development in overcoming social disadvantage. Background paper prepared for the Education for All Global Monitoring Report 2012. Presented at a meeting of experts on "Expanding opportunities for the marginalized through skills development" organized by the GMR and BMZ in Bonn, Germany (3-4 November 2010).

Ahmed, K. (2020). Patterns of social reactions to COVID-19 pandemic; reasons \& proposed ways to overcome. Advanced Journal of Social Science, 7(1), 54-59. 
Mugabi et al., Adv. J Social Sci.; Vol. 9, Issue 1, pp: 10-26, 2021

Africa Progress Report. (2012). Jobs, Justice and Equity: Seizing opportunities in times of global change. Geneva: Africa Progress Panel.

African Union \& African Union Development Agency (2020). COVID-19 and its implications for skills development. Special Edition, Skills Initiative for Africa.

Alzira .M, Oleg. P, \& D. Buque (2015). Towards programme improvement in non-formal skills development programmes and training in Mozambique. Problems of education in the $21^{\text {st }}$ century: Volume 67.

Bennell, P. (1999). Learning to change: Skills development among the economically vulnerable and socially excluded in developing countries. Geneva, Switzerland: ILO.

Blaak, M., Openjuru, G. L., \& Zeelen, J. (2013). Non-formal skills development programmes in Uganda: Practical empowerment through a workable alternative. International Journal of Educational Development, 33(1), 88-97.

Bryman, A. (2001).Social research methods, Oxford University Press: Oxford.

Campbell. D \& Ahmed, I. (2012). "Employment-Led Growth and Growth-Led Employment in the Recovery," in the Global Crisis: Causes, Responses, and Challenges, (Geneva: ILO, 2011), Chapter 8.

Conen, C., \& Rutten, D. (2003). Early School Leaving and the Role of Career Guidance and Counselling. UNIN Adult Education Series, 7.

Castro, C. (1996). The elusive fit between training and its demand. IDB: Washington D.C.

Chinnayan, S. (2020). COVID-19 Social Work Scope and Intervention in A Tertiary Care Hospital. Advanced Journal of Social Science, $7(1), 92-95$.

Descombe, M. (2003). The research guide for small-scale social research projects, (2nd edn). Philadelphia: Open University Press.

Fluitman, F. (1998). Training for work in the informal sector in developing countries: issues and good practice. ILO. Geneva.

Freire, P. (2005). Pedagogy of the oppressed, (30th edn). New York/London: continuum.

Gallagher, K., \& Yunusa. M. (1996). Passing the buck: structural adjustment and the Nigerian urban informal sector. UNRISD: Geneva.

Godfrey, M. (1997). 'Can training help disadvantaged groups in developing countries and the transitional economies?' ILO, mimeo. Background paper for the ILO World Employment Report. ILO: Geneva.

Government of Uganda. (2020). National Development Plan (2020/21 - 2015/16): Growth, employment and socio-economic transformation for prosperity. Kampala: National Planning Authority.

Green, A. (2021). The COVID-19 crisis and implications for skills development and the skills system. In Productivity and the Pandemic. Edward Elgar Publishing.

Golafshani, N. (2003). Understanding validity and reliability in qualitative research. The Qualitative Report 8(4), 597-607.

Grandstaff, M. (1978). Non-formal education as a concept. Prospects, 8(2), 177-182.

Grierson J.P. and I. Mckenzie (eds.). (1996). Training for self-employment through vocational training institutions. ILO International Training Centre. ILO: Turin.

Harper, M. (1996). Urban planning and the informal sector. Regional Development Dialogue, 17, 6.

Hakim, C. (2012). Research Design: Successful Designs for Social Economics Research. Routledge: London.

Indabawa, S. A., Indabawa, S., \& Mpofu. S. (2006). the social context of adult learning in Africa. Pearson South Africa.

International Labour Organization (ILO) \& World Bank (2021). Skills development in the time of COVID-19: Taking stock of the initial responses in technical and skills development programmes and training. Geneva- ILO.

ILO. (1998). Gender guidelines for employment and skills training in conflict-affected countries. Training Policies and Systems Branch. ILO: Geneva.

ILO. (1997). Vocational training and lifelong learning of women. ILO: Geneva. ILO. (1994). the rural informal sector in Asia: policies and strategies. ILO: Geneva.

ILO/CINTERFOR. (1997). Training and labour: past and present. CINTERFOR. Montevideo.

Jarvis, P. (Ed.). (2006). the theory and practice of teaching, (2nd edn.).London/New York: Routledge.

Jjuuko, R. (2012). Developing vocational skills of youths with incomplete schooling: A case study of private provision in Uganda. Saarbrucken: LAP LAMBERT Academic Publishing.

Kawuki, J., Sserwanja, Q., Obore, N., Wang, J., \& Lau, J. (2020). Reflecting on the first two COVID-19 deaths in Uganda: a public health case study.

Kearns, P. (2001a). Generic skills for the new economy: A review of research relating to generic skills. National Center for Vocational Education Research, Adelaide.

Kende-Robb, C. (2012).In: Africa Progress Report 2012-Jobs, Justice and Equity: Seizing Opportunities in Times of Global Change, Geneva: Africa Progress Panel.

King. K. (1996). Training for self-employment through vocational training institutions: Lessons from experience. In Grierson and McKenzie, 1996.

Koshy, V. (2010). Action research for improving educational practice: A step-by-step guide. (2nd edn). London: Sage.

Kulkarni, S. S., \& Lorenz, K. E. (2020). Social Implications of COVID-19 Deaths: Analyzing Race, Ethnicity, Socio-Economic Conditions, Gender, and Age for the US. Advanced Journal of Social Science, 7(1), 163-180. https://doi.org/10.21467/ajss.7.1.163-180

Lalonde, R.T. (1995). The promise of public sector programmes.

Liamputtong, P., \& Ezzy, D. (2005). Qualitative research methods (second ed.). Victoria: Oxford University Press.

Lim, Z., Anderson, C., \& McGrath S. (2012). Professional skills development in a resource-poor setting: The case of pharmacy in Malawi. International Journal of Educational Development 32(5), 654-664.

Livia, A., Oriana, B., Vitorio, B., Robin., B., Imran, R., and Vitali, A. (2021). Vocational training, on the job training, and resilience to the COVID-19 shock.

McGrath, S. (2012b). Skills development programmes and training for development: A policy in need of a theory? International Journal of Educational Development 32(5) 623-631. 
McGrath, S., \& Lugg, R. (2012). Knowing and doing skills development programmes and training reform: Evidence, learning and the policy process. International Journal of Educational Development 32(5), 696-708.

Minnis, J. R. (2006). Non-formal education and informal economies in sub-Saharan Africa: Finding the right match. Adult Education Quarterly, 56(2), 119-133.

Ministry of Education and Sports. (2020). Preparedness and Response Plan for COVID-19. Ministry of Education and Sports Taskforce for COVID-19. Kampala: MoES.

MoES. (2012). The Education and Sports Sector Annual Performance report (ESSAPR) 2011/2012. Kampala: MoES.

MoES. (2011). Skilling Uganda: The BTVET Strategic Plan 2012-2022. Kampala: MoES.

Ministry of Health, Uganda. (2020). Coronavirus (Pandemic) COVID-19. Uganda: MoH-Uganda. Available from: https://www.health.go.ug/COVID/

Nampota, D. (2010). Development and implementation of non -formal education programmes for early school leavers: lessons in Malawi. In: Zeelen, J., Van der Linden, J., Nampota, D., Ngabirano, M. (Eds.), The Burden of Educational Exclusion. Understanding and Challenging Early School Leaving in Africa. Sense publishers, Rotterdam, pp. 297-316.

Olagunju, O. S., Bolarinwa, O. A., \& Babalola, T. K. (2020). Social Distancing, Lockdown Obligatory, and Response Satisfaction During COVID-19 Pandemic: Perception of Nigerian Social Media Users. Advanced Journal of Social Science, 7(1), 44-53. https://doi.org/10.21467/ajss.7.1.44-53

Olmec. (2007). restart: innovative approaches to early school leaving in England and Wales. Durham St Vauxhall: Olmec.

Openjuru, G. L. (2010). Government education policies and the problem of early school leaving: the case of Uganda. The Burden of Educational Exclusion. Understanding and Challenging Early School Leaving in Africa, ed. J. Zeelen, J. van der Linden, D. Nampota, and M. Ngabirano, 22-47. Rotterdam: Sense Publishers.

Powell, L. (2012). Reimagining the purpose of VET-Expanding the capability to aspire in South African further education and training students. International Journal of Educational Development, 32(5), 643-653.

Quisumbing, L. R. (2001, March). The importance of values education for TVET and its economic and human resource development program. UNESCO Asia Pacific Conference, Adelaide.

Reinharz, S. (1997). Who am I? The need for a variety of selves in the field. Reflexivity and voice, 3-20. Sage: Thousand Oaks.

Ritchie, J., \& Lewis (2008). Qualitative research practice: A guide for social science students and re-searchers. London: SAGE publications.

Robeyns, I. (2003). Sen's capability approach and gender inequality: selecting relevant capabilities. Feminist economics, 9(2-3), 61-92.

Sanyal, B. (1996). Intention and outcome: formalization and its consequences. Regional Development Dialogue, 17, 5.

Sappa, V., \& Bonica, L. (2011). School-to-work transitional outcomes of a group of Italian school dropouts: Challenges for promoting social inclusion. Education + Training 53(7), 625-637.

Sen, A. (2004). Rationality and freedom. Harvard University Press.

Sen, A. K. (2001). Development as freedom. Oxford University Press.

Sen. A. (1999). Development as freedom. New York: Knopf.

Stake, R. (1998). Case Studies. In Denzin, Nk \& Lincoln, Y. (Eds.) Strategies of Qualitative Inquiry. Thousand Oaks, London and New Delhi.

Tashakkori, A., and Teddlie, C. (2003). Handbook of mixed methods in social and behavioral research. Thousand Oaks, CA: SAGE.

Tukundane, C. (2015). Using participatory action research to improve vocational skills training for marginalised youth in Uganda: experiences from an early school-leavers' project. International journal of Training and Research 13 (3) $246-261$.

Tukundane, C., \& Blaak, M. (2010). Towards new intervention programmes for early School leavers in Uganda. In Zeelen, J. Van der Linden, D. Nampota and M. Ngabirano (Eds.), the burden of educational exclusion: Understanding and challenging early school leaving in Africa (pp. 209-224). Rotterdam: Sense Publishers.

Tukundane, C. Minnaert, A, Zeelen, J and Kanyandago, P. (2015). Building vocational skills for marginalised youth in Uganda: A SWOT analysis of four training programs. International Journal of Educational Development, 40 (4) 134-144.

Tumwesige, J. (2020). COVID-19 Educational Disruption and Response: Rethinking e-Learning in Uganda. University of Cambridge.

UBOS. (2010). Uganda National Household Survey 2009/2010: Report on the socio-economic module. Kampala: Uganda Bureau of Statistics.

UBOS (2016). Labour market transition of young people in Uganda: Highlights of the School-to-Work Transition Survey 2015. Kampala. Uganda Bureau of Statistics.

United Nations. (2009).The Millennium Development Goals Report. Available: http://www.un.org/millenniumgoals/pdf/MDG_Report_2009_ENG.pdf. [Accessed: $20^{\text {th }}$, August, /2021].

United Nations Educational, Scientific and Cultural Organization. (2020). Education. From disruption to recovery. UNESCO. https://en.unesco.org/COVID19/educationresponse

UNICEF. (2020). COVID-19 and Children. UNICEF data hub UNESCO. (2012b). Youth and skills: putting education to work. The EFA Global Monitoring Report 2012. Paris: UNESCO Publishing.

UNESCO. (2012a). transforming technical and skills development programmes and training: Building skills for work and life. Main document for UNESCO Third International Congress on Technical and Skills development programmes and Training, Shanghai, People's Republic of China, 13-16 May 2012.

UNESCO. (2012). Youth and skills: putting education to work. The EFA Global Monitoring Report 2012. Paris: UNESCO

Publishing.

UNESCO-IBE. (2010). World Data on Education VII Ed. 2010/11. Uganda. Geneva: UNESCO-IBE.

UNESCO. (2010). Reaching the marginalized. Education for All global monitoring report 2010. UNESCO.

UNESCO. (2013). Schooling for millions of children jeopardized by reductions in aid. Policy Paper 09. Paris: UNESCO. 
Mugabi et al., Adv. J Social Sci.; Vol. 9, Issue 1, pp: 10-26, 2021

United Nations.(2015). Sustainable Development Goals: 17 Goals to Transform Our World. United Nations, [Online]. Available: https://www. UN. Org/sustainable development/energy/.[Accessed 08 August 2018].

Waniha, A.G. (2008). Assessment of the implementation of non-formal education and complementary basis education programme in Tanzania. Un published results master's research. University of Groningen, Groningen, the Netherlands.

World Bank. (2006b) World development report 2007. Development and the Next generation, Washington, DC. World Bank.

World Education Forum, 2000. Dakar Framework for Action. Available: http://www.unesco.org/education/efa/ed_for_all/dakfram_eng.html. [20 ${ }^{\text {th }}$, August, 2021]

Yassunaga, M. (2014). Non-formal education as a means to meet learning needs of out-of-school children and adolescents. Background Paper prepared for fixing the Broken Promise of Education for All: Findings from the Global Initiative on Out-of-School Children. Montreal: UNESCO Institute for Statistics, 120.

Publish your research article in AIJR journals-

$\checkmark \quad$ Online Submission and Tracking

$\checkmark$ Peer-Reviewed

$\checkmark \quad$ Rapid decision

$\checkmark \quad$ Immediate Publication after acceptance

$\checkmark \quad$ Articles freely available online

$\checkmark \quad$ Retain full copyright of your article.

Submit your article at journals.aijr.org
Publish your books with AIJR publisher-

$\checkmark \quad$ Publish with ISBN and DOI.

$\checkmark \quad$ Publish Thesis/Dissertation as Monograph.

$\checkmark \quad$ Publish Book Monograph.

$\checkmark \quad$ Publish Edited Volume/ Book.

$\checkmark \quad$ Publish Conference Proceedings

$\checkmark \quad$ Retain full copyright of your books.

Submit your manuscript at books.aijr.org 